Beatty, B.L., and Heckert, A.B., (2009) A large archosauriform tooth with multiple supernumerary carinae from the Upper Triassic of New Mexico (USA), with comments on carina development and anomalies in the Archosauria. Historical Biology, 21(1/2): p. 57-65. (March-June 2009) Published by Taylor \& Francis (ISSN: 1029-2381).

\title{
A large archosauriform tooth with multiple supernumerary carinae from the Upper Triassic of New Mexico (USA), with comments on carina development and anomalies in the Archosauria
}

Brian Lee Beatty and Andrew B. Heckert

\begin{abstract}
Here we report a tooth of a large archosauriform from the Upper Triassic of New Mexico, USA that displays developmental anomalies of carina formation. This tooth has two supernumerary carinae, both on the lingual side of the tooth. Previously, carina anomalies of this sort were primarily known from theropod dinosaurs, but always from the labial surface. Integrating this specimen into a reassessment of the published accounts of carina anomalies in other fossil diapsids reveals that supernumerary carinae are more widespread throughout Archosauriformes than previously reported. Our interpretation of this developmental anomaly highlights the present lack of understanding of tooth development in archosaurs, particularly carina formation, and suggests that crown morphology development in archosauriforms may be constrained differently than it is in mammals. This developmental constraint may explain the differences observed between the complexity found in mammal and archosauriform cusp morphology.
\end{abstract}




\section{INTRODUCTION}

Carinae are the convex, raised edges that follow the longitudinal axis of a tooth that are found on the mesial and/or distal edges of the ziphodont teeth of many vertebrates. Though not found in the Lissamphibia (Peyer 1968; Duellman and Trueb 1986), carinae are common in diapsids, including iguanids (Throckmorton 1976), and especially archosauriforms, including crocodyloforms, dinosaurs and birds (Langston 1956; Galton 1986; Currie 1987). There is a reason to question their homology, however, as carinae are found in various ziphodont-like dentitions of many other groups, including the canines of some large cats (Martin 1980) and the 'homodont' teeth of some odontocetes (Dubrovo and Sanders 2000; Uhen 2008). Carinae are specializations for processing foods, although they are rarely considered as a means of differentiating adjacent tooth functions the way mammalian cusps are used to determine heterodonty. For example, the crown morphology, including carina morphology, of prosauropods have been hypothesized to indicate herbivory like that seen in iguanids (Throckmorton 1976), yet this have become questionable in light of comparisons of crown morphology of iguanids with modern faunivorous diapsids (Galton 1986; Barrett 2000). The carina itself is probably best explained as an adaptive structure for enhancing crack propagation in mechanically tough foods like meat (Purslow 1991), and the addition of denticles for serration make them even more effective in this manner (Frazzetta 1988; Abler 1992). Carinae are usually found as single ridges on the mesial and/or distal edges of teeth, although their position may vary depending on where the tooth is located on the tooth row (Smith 2005).

Occasionally, more than one carina is observed on the mesial or distal edges of the teeth of theropod dinosaurs, usually forming a forked structure from the primary carina, commonly referred to as a 'split carina'. Split carinae are known in several Cretaceous theropods, including tyrannosaurids (Erickson 1995), dromaeosaurids (Fiorillo and Gangloff 2000) and carcharodontosaurids (Candeiro and Tanke 2008; Sereno and Brusatte 2008). Split carinae have also been reported from unidentified theropod teeth from the Late Cretaceous Minhe Formation of China (Bohlin 1953). The Late Triassic basal archosaurs, the phytosaurs, have also been reported to have these (von Meyer 1861; Hungerbu"hler 2000). In the case of Nicrosaurus, only a single tooth from an entire known tooth row had a split carina, making it clear that this is an unusual variation and not a taxonomically distinctive feature that likely had any phylogenetic or regular functional importance (Hungerbu“hler 2000).

Here we report a tooth of a Late Triassic nondinosaurian archosauriform with two supernumerary carinae, one near and parallel to the anterior carina and one on the proximal half of its lingual side. Supernumerary carinae can be distinguished from split carinae in that they never join, but are parallel tracks of distinct carinae. This distinction is potentially very important in understanding how carinae develop and evolve (which will become evident in discussions about tooth development below). It is unclear from the descriptions presented in other studies (Erickson 1996; Candeiro and Tanke 2008) that this distinction has been made before, and the distribution of supernumerary carinae may be more extensive than presently known. The only other report of supernumerary carinae (recognised from the published figure, but not reported as supernumerary carinae) is a single tyrannosaurid tooth with four supernumerary carinae (Abler 1997; housed at the Royal Tyrell Museum of Palaeontology, but 
no catalog number reported). The specimen reported here represents the first record of a supernumerary carina on the lingual side of a tooth in any non-dinosaur archosauriform and the oldest record of this sort of developmental anomaly in Archosauromorpha and, so far as we can tell, Diapsida.

\section{Institutional abbreviations:}

NMMNH; New Mexico Museum of Natural History and Science, Albuquerque, USA; SMNS; Staatliches Museum für Naturkunde, Stuttgart, Germany.

\section{Provenance and age}

The tooth described here (NMMNH P-18306 from locality 3254) was originally found in 10 pieces scattered across a low slope of the Bluewater Creek Formation in the Zuni Mountains of west-central New Mexico (Heckert 1997). The Bluewater Creek Formation in New Mexico yields a fauna of fragmentary vertebrates of Late Triassic age historically considered Adamanian (Carnian) (Heckert 1997; Heckert and Lucas 2003; Figure 1). Heckert et al. (2007) reported an incomplete osteoderm of the aetosaur Tecovasuchus from the lower Bluewater Creek Formation near locality 3254, which they considered additional evidence of an Adamanian age for the Bluewater Creek Formation. The Placerias quarry in the lower Bluewater Creek Formation in Arizona yields an age diagnostic fauna including the aetosaurs Desmatosuchus haplocerus and Stagonolepis wellesi and the phytosaurs Rutiodon sp. And Parasuchus (1/4Paleorhinus) sp. (Lucas et al. 1997; Heckert et al. 2005), a fauna that appears to approximate the boundary between the Adamanian and the older, Otischalkian faunas (Lucas et al. 2007). While some have advocated a 'long Norian' interval that encompasses much of what was previously regarded as Carnian (Furin et al. 2006), tying nonmarine units to the marine timescale remains problematic. 


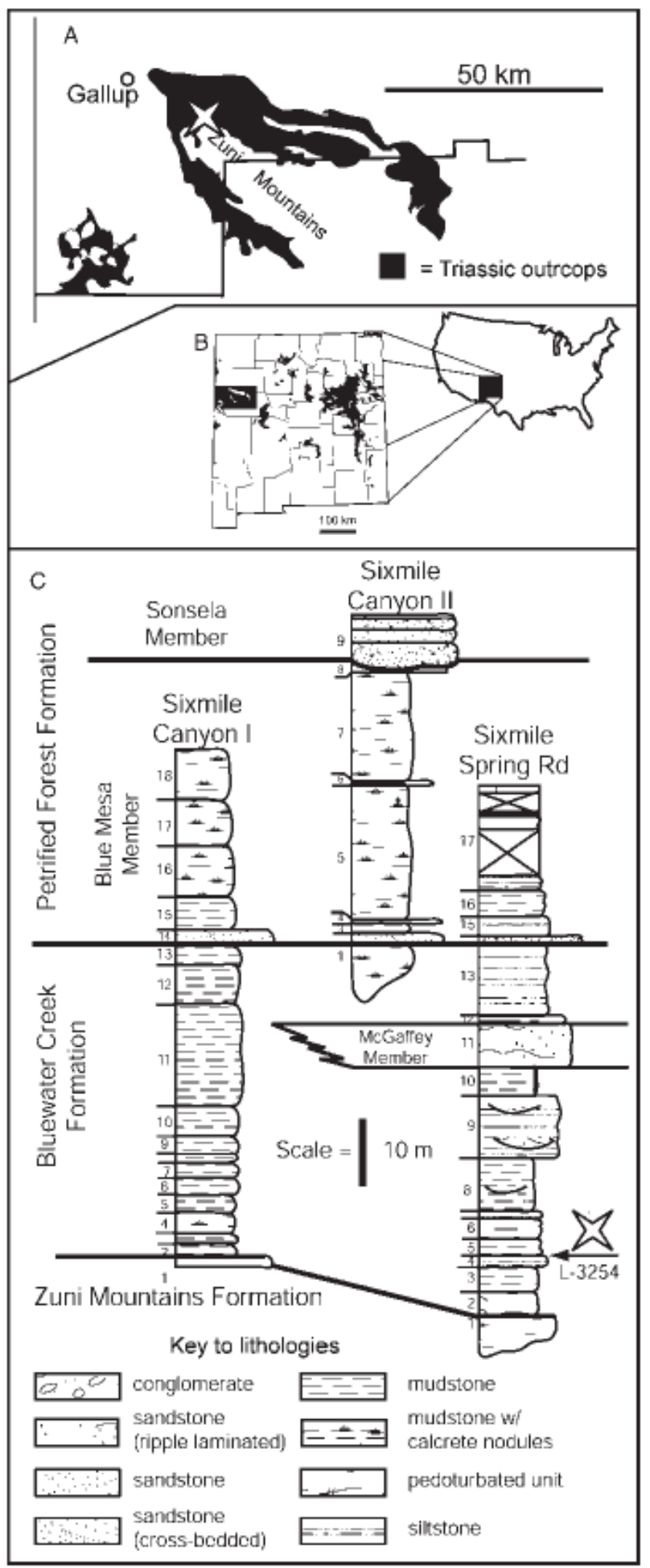

Figure 1. Geographic and stratigraphic provenance of the specimen described here. (A) Distribution of Triassic outcrops in west-central New Mexico, USA and star marks Sixmile Canyon; (B) inset map showing area in (A) relative to New Mexico and the USA; and (C) measured sections after Heckert and Lucas (2003; Figure 5), star shows the stratigraphic position of the locality (L-3254) that yielded the specimen described here. 
Heckert (1997; Figure 3(a) and (b)) described and illustrated the specimen, attributing it to a large, heterodont phytosaur. Although phytosaurs are the only common archosaur in the Bluewater Creek Formation that could possess teeth this large, the tooth does not closely resemble known phytosaur teeth. In particular, the tooth is asymmetrical in occlusal view, with a flattened lingual side and a convex labial surface forming a 'D-shaped' cross-section. The only phytosaur teeth that typically have 'D-shaped' crowns are the posterior 'blade teeth' identified as maxillary and posterior dentary teeth by Hungerbu"hler (2000; see also Hunt 1989). However these teeth are generally equally as mesio-distally long as tall, whereas the crown height of P18306 is more than twice the mesiodistal length. Thus, it is unlike the teeth in even the most heterodont phytosaurs, such as Nicrosaurus, where even the very large 'tip-of-snout' teeth typically have a convex lingual surface (Hungerbu"hler 2000; Figure 3).

Identifying isolated Triassic amniote teeth is problematic. Ziphodont, serrated teeth were traditionally assigned to 'Reptilia indeterminate' or 'Thecodontia' prior to the application of cladistic methods to archosaur taxonomy. Godefroit and Cuny (1997; see also Heckert 2004) built upon existing phylogenies of basal archosaurs to identify the following synapomorphies of archosauriform teeth: thecodont implantation and conical to recurved crown, with anterior and distal carinae that may be serrated or otherwise modified by denticles. The presence of a large basal resorption pit where the root was resorbed prior to replacement indicates that this tooth was originally the codont before it was shed. The conical profile, and mesial and distal carinae bearing serrations composed of numerous equi-sized denticles in NMMNH P-18306 demonstrate that this tooth possesses all of the synapomorphies of Archosauriformes sensu Godefroit and Cuny (1997).

Within Archosauriformes, there are numerous taxonomic possibilities for a tooth of Late Triassic age. As discussed in the previous paragraph, it differs from known phytosaur teeth, although it is possible that the developmental abnormalities we document here also resulted in an atypical overall tooth morphology. We consider this unlikely and therefore do not assign the tooth to the Phytosauria, contra Heckert (1997). Among other Late Triassic archosaurs, it is obviously not the tooth of an aetosaur as these possibly herbivorous archosaurs have a reduced and secondarily generalised dentition (e.g. Heckert and Lucas 2000a; Desojo and Ba'ez 2007). Triassic theropod dinosaurs, even larger, younger taxa such as Liliensternus (teeth are not yet known from Gojirasaurus), are too small to yield such teeth (Carpenter 1997; Heckert and Lucas 2000b; A.B. Heckert, personal observation), as are various less derived taxa leading to dinosaurs (Langer and Benton 2006; Irmis et al. 2007a), and generally have laterally compressed teeth, so we consider a dinosauriform affinity extremely unlikely. Among large Triassic crown-group archosaurs, ornithosuchids are extremely rare in the Chinle (Long and Murry 1995) and all known taxa are much smaller than could yield such a tooth (Walker 1964).

Much larger and more common than dinosaurs and ornithosuchids in this interval are 'rauisuchians' sensu lato (including poposaurids, shuvosaurids, etc.; Long and Murry 1995), including the large Postosuchus, which is known from the Bluewater Creek Formation at the Placerias quarry (Long and Murry 1995; Lucas et al. 1997; Heckert et al. 2005). 'Rauisuchians' are almost certainly not a monophyletic group (Gower 2000; Nesbitt 2005a; Jalil and Peyer 2007), but at least some of these taxa possess large teeth superficially similar in shape to 
NMMNH P-18306. However, even large 'rauisuchians' such as Postosuchus and Saurosuchus tend to have more strongly laterally compressed teeth than seen in NMMNH P-18306 (Sill 1974; Chatterjee 1985; Alcober 2000). There are also a few, very large-bodied, more derived crurotarsans such as the crocodyliform Redondavenator in the Chinle, although this taxon is very much younger and appears to have more conical to laterally compressed teeth, as do sphenosuchians generally (Nesbitt et al. 2005; Figure 2(a) and (b)). The possibility also exists that NMMNH P- 18306 represents a large archosauriform, taxon outside of the crown group archosaurs, such as Arizonasaurus (Nesbitt 2005b), an erythrosuchid (e.g. Gower 2003) or a proterochampsid (Romer 1971) not previously known from the Chinle. Given that the Bluewater Creek Formation is very much younger than the Middle Triassic strata that yield the youngest records of these taxa we consider this possibility unlikely.

In summary, we consider a possible 'rauisuchian' affinity for NMMNH P-18306 most likely based on its large size and overall morphology. We cannot, however, rule out many other archosauriform taxa, including the possibility that it is a malformed phytosaur tooth, and therefore can only definitively refer it to Archosauriformes sensu Godefroit and Cuny (1997) and Heckert (2004).

\section{DESCRIPTION}

NMMNH P-18306 is a left upper tooth of an archosauriform (Figure 2). It is approximately 70mm long from base to tip, and is slightly curved posteromedially. More specifically, its length from tip to the base of the crown along the distal edge is $68.38 \mathrm{~mm}$, and from the tip to the base of the crown along the mesial edge is $72.82 \mathrm{~mm}$ in length. The labio-lingual width at the base of the crown is $23.85 \mathrm{~mm}$. 


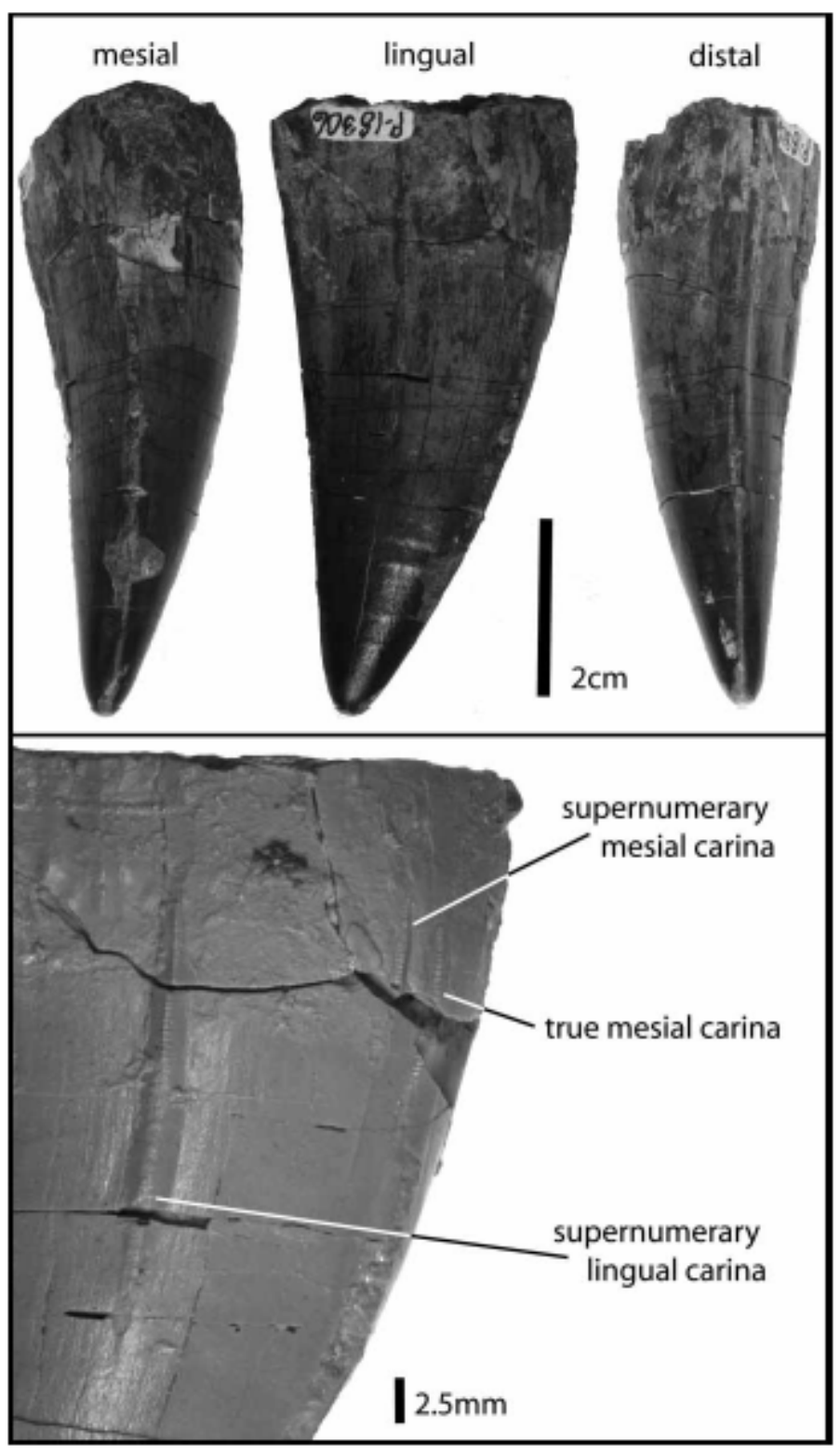

Figure 2. NMMNH P-18306 a large archosauriform tooth in mesial, lingual and distal views (top) and closeup of lingual side of cast of NMMNH P-18306 with labels indicating the location of carinae.

This tooth in other archosauriform specimens usually has carinae on the mesial and distal edges of the tooth reaching from near the tip to the base of the crown, here referred to as the true mesial carina and true distal carina, respectively. The true mesial and distal carinae lie closer to the lingual half of their respective edges, making the portion labial to the carinae appear larger than the lingual portion. The true mesial carina extends $62 \mathrm{~mm}$ from the tip, but does not stand out with as much relief as the true distal carina. The true distal carina is less curved than the true mesial one, and extends for most of the $68 \mathrm{~mm}$ length of the distal edge of 
the tooth. Both true carinae are worn or broken within $10 \mathrm{~mm}$ of the tip, making it difficult to determine their unworn/undamaged morphology and extent. Denticles along the mesial carina are too damaged to measure accurately at its mid-length, but they appear to have a serration density of 13 per $5 \mathrm{~mm}$ near the base of the crown, as per Farlow et al. (1991). Denticles on the distal carina are well-preserved, allowing for a measure of serration density at its mid-length (serration density $1 / 412$ per $5 \mathrm{~mm}$ ).

About $42 \mathrm{~mm}$ from the tip, running parallel to the true mesial carina, there is a supernumerary mesial carina that is slightly less pronounced than the true mesial carina. This supernumerary mesial carina is approximately $23 \mathrm{~mm}$ in length and terminates just $2.5 \mathrm{~mm}$ basal to the level that the true mesial carina terminates. The middle third of the supernumerary mesial carina is damaged, unfortunately, but proximal to this damage one can see distinct denticles that are the same size as the denticles on the true mesial carina. Unfortunately, this carina is very close to the base of the crown, and the segment of this carina preserving denticles is not $5 \mathrm{~mm}$ long, making it not ideal for a serration density measurement. Though if one were to extrapolate from a measurement of serration density of 6.5 per $2.5 \mathrm{~mm}$ of its length, one gets a serration density of 13 per $5 \mathrm{~mm}$, which is identical to the serration density of the segment of the mesial carina (see above) that lies beside it. This superficially resembles the right seventh tooth of Hungerbu"hler's premaxillary tooth set (pm 2) of the phytosaur Nicrosaurus, SMNS 13078 (Hungerbu"hler 2000; Figure 3(c)). Though that tooth of Nicrosaurus was reported as having a split and partially doubled carina, it is clear that this carina was not connected to the true mesial carina and would be better classified as a supernumerary mesial carina.

On the lingual surface, exactly in between the true mesial and distal carinae, there is a second, lingual supernumerary carina. The lingual supernumerary carina is $31 \mathrm{~mm}$ long, starting $33 \mathrm{~mm}$ from the tip and ending approximately $9 \mathrm{~mm}$ from the broken edge of the crown base. Although its surface is slightly damaged, it too has denticles on it of approximately the same size and spacing (serration density $1 / 412$ per $5 \mathrm{~mm}$ ) as those of the true carinae.

It should also be noted that when observed under a dissecting microscope, it appears that the enamel is uniformly thick $(p 1 \mathrm{~mm})$, even at the carinae. This is similar to previous observations from studies of enamel microstructure for theropods, and many other archosaurs (Sander 1999).

\section{DISCUSSION}

\section{A brief review of tooth development in amniotes}

For the purposes of background with concepts and terminology necessary to understanding aspects of tooth development discussed below, here we will briefly review what is known of how amniote teeth develop (a nice summary can be found in Thesleff 2003).

Most amniotes, with few exceptions, have teeth that develop via an interaction of some basic embryonic tissues that lie in close proximity, especially in the oral cavity: epithelium and mesenchyme. The epithelium, in the form of a thickened layer of ectoderm, covers the surface 
of what will become the oral cavity and gingiva. This ectoderm forms a thickening, called a placode, that buds to the underlying neural-crest derived mesenchyme (that will become the dentine). This placode stimulates the underlying mesenchyme to form a convex structure, called the cap stage, that begins to form the tooth shape. The region(s) where this budding occurs first, and therefore where the tip of the cusp ultimately forms, is called the enamel knot. Enamel is the mineralised exterior of a tooth that is secreted by ameloblasts (the term for enamel deposition and formation is amelogenesis), derived from that ectoderm placode, that begin their pathway of secretion from the enamel-dentine junction (EDJ, the place where the epithelium and mesenchyme meet) and travel outward to what will become the outer surface of the tooth itself. While enamel deposition starts from the EDJ going out to what will become the outer surface of the tooth, the initiation of cusp morphology follows after the enamel knot(s). The means by which cusp morphology is determined from cusp tip to the base of the crown can be roughly compared to the extrusion of play-dough through a specified shape that is modified during development by differentially expressed proteins (such as ectodin, see Kassai et al. 2005).

The genetics of how enamel knots, and other subsequent cusps develop is backed up by an extensive amount of work by previous authors, though with few exceptions this work is mostly focused on mammalian models. For further background on the developmental genetics of tooth development in amniotes, we suggest reading works by Thesleff (2003), Delgado et al. (2005) and Sire et al. (2007).

\section{What causes carina deformities?}

Although Erickson (1995) considered that split carinae in tyrannosaurids might have been caused by trauma, he preferred a genetic cause. Tooth deformities caused by trauma are not unheard of, as it has been well-established as a common cause of unusual tooth morphologies in elasmobranchs (Becker et al. 2000). But in these cases, tooth deformities do not result in a multiplication of structures, but instead the damage and healing of them occurs before mineralisation is complete, usually leading to splits in the crown itself. It is difficult to conceive of a manner in which injury would cause the addition of a supernumerary carina with serrations.

Erickson (1995) also suggested aberrant tooth replacement as a possible cause. Tooth replacement in alligators, and presumably other archosaurs, is a complex succession of fully and partially developed teeth, including some teeth that never fully form (Edmund 1960, 1962; Westergaard and Ferguson 1990). It is difficult to imagine how tooth replacement could cause a supernumerary carina, as tooth crown enamel development starts from an enamel knot at its tip and gradually follows toward its base, much like that seen in mammals (Kassai et al. 2005) and squamates (Delgado et al. 2005). Therefore, something during tooth eruption would have to cause some damage to the region forming the carina such that it is spontaneously duplicated in another neighbouring region. This would have to happen early enough in tooth development that it seems inconceivable that an overlying tooth could affect the location of this tiny carinaforming region of the developing tooth. 
Also, although elaborate enamel surfaces in many durophagous reptiles are due to changes in enamel

thickness overlaying a mostly smooth EDJ, the enamel thickness of many archosaurs is, as far as we know (Sander 1999) evenly thin. This thin enamel typically overlies a more complex EDJ, and can even be thinnest at carinae and the denticles on those carinae (Sander 1999). That would imply that the formation of supernumerary or split carinae are the result of abnormal dentine formation, and not abnormal formation of the enamel crown overlaying it. Carina formation, therefore, is something that occurs as a result of dentine development, not necessarily enamel development except in the sense that signals from the enamel knot (which is determined by epithelial factors) affect both epithelial (enamel organ) and mesenchyme cells (which will become the dentine of the tooth; Thesleff 2003). Dentine growth in modern Alligator is an incremental series of cones added to the inner surface of the pulp cavity at a relatively rapid rate that decreases with age (Erickson 1996). Those cones developed subsequent to the initial cone that contacts enamel, therefore, should have no effect on the carina shape.

The role of gene expression in the formation of carinae is, at present, unknown. Considering that much of what is known of the genetic expression of tooth formation in most vertebrates is centred on amelogenesis, it is unfortunate that the little we know about gene expression in tooth formation outside of mammals (Toyosawa et al. 1998, 1999; Shintani et al. 2002, 2006; Harris et al. 2006; Sire et al. 2007; Buchtova' et al. 2008) is likewise not helpful in understanding how these carinae form, either abnormally or normally. But considering the conservative nature of genes controlling enamel formation and epithelial- mesenchyme interactions (Sire et al. 2007), and the fact that enamel knots are found in alligators (Westergaard and Ferguson 1986), it may be presumed that carinae (including supernumerary ones) develop after primary enamel knot formation and perhaps form in a process similar to secondary enamel knot formation. This may explain why the supernumerary carinae run parallel to the normal carinae, even though they do not extend the full length of the tooth. Whether this is controlled in the same way or not is uncertain, although enamel thickness in carinae is clearly not modified like it is in secondary folds and crests of mammal enamel traits. Regardless it appears clear that these supernumerary carinae must result from some genetic expression. Perhaps the most interesting facet of these supernumerary carinae is that they maintain a serration density identical to the serration density of the true carinae that run parallel to them, even forming the smaller denticles (and therefore slightly greater serration density) near the base of the crown. This suggests that despite the potential flexibility in how carinae may form anomalously, serration density is independent of those anomalies and maintains its developmental rigor, lending support to notions that serration density is a phylogenetically informative character (Farlow et al. 1991).

\section{Phylogenetic distribution}

Erickson (1995) ultimately favoured the idea that the likely cause of split carinae found in allosaurids and tyrannosaurids was some shared gene for potential tooth deformities going back to their tetanuran ancestry. As this report and others on phytosaurs (Hungerbuhler 2000) suggests, if this shared potential is optimised on a cladogram it certainly goes back further into 
Archosauria as a whole (Figure 3). This is interesting, particularly because it means that the possible genetic cause of this anomaly might be found in other, non-theropod dinosaurs and other archosaurs. What does this say for the potential for dental variation in these groups? We will not know without further investigations of large samples of species from single localities, but it is interesting to consider that such genetic anomalies might be a source of variation that could be co-opted into functionally useful morphology that might subsequently develop into more complex tooth morphologies.

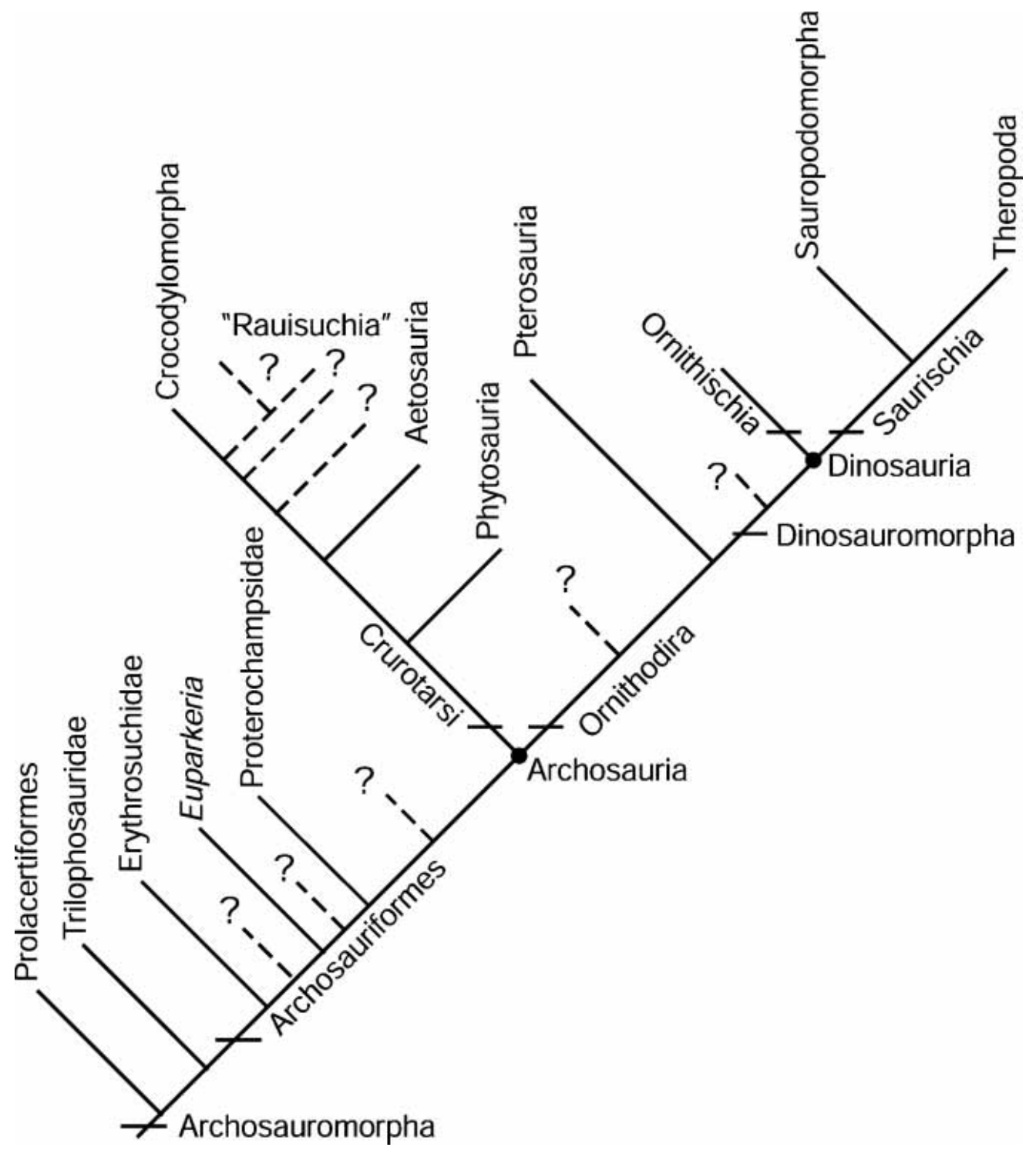

Figure 3. Simplified cladogram of Archosauromorpha showing the general phylogenetic relationships of taxa discussed in this paper. Dashed lines and question marks (?) indicate possible of the affinities for the tooth described here, but a 'rauisuchian' origin appears most likely. Principally after Sereno (1991), Gauthier (1994) and Brusatte et al. (2008). 


\section{CONCLUSION}

Dental anomalies of fossil organisms that are the result of errors in development are commonly lumped with paleopathologies (Candeiro and Tanke 2008), even though developmental errors may have no deleterious effect or disease as a root cause. The development of a supernumerary carina on the tooth of an animal that normally only has mesial and distal carinae is such a feature. Though not particularly well understood, there is virtually no reason to suggest that its presence harmed the individual organism's chances of survival, and indeed this tooth was shed by an animal that was very large by Triassic standards and thus almost certainly an adult. Because this sort of developmental anomaly is more discrete and striking than other aspects of variation, it stands out compared to developmental anomalies of more continuous variables, such as bone length or width. In this way, a supernumerary carina may be compared with other variations when delimiting species, and could even be viewed as a character of little use in species diagnoses according to population aggregation analysis methods (Davis and Nixon 1992), simply because it is obviously variable. Variation due to ontogeny or developmental variation is hardly studied in archosaurs, and aside from numerous case reports, only a handful of studies attempt to compare frequencies of anomalies in whole populations of living animals (Hall 1985) or fossil samples (Smith et al. 2005). Perhaps with further studies of how carinae vary among modern toothed archosaurs (Crocodylia) and other diapsids in addition to fossil groups for which large samples are known, we might gauge the utility of carina characters of different types for certain groups. If numerous carinae are commonly variable for archosaurs, but very species-specific for other diapsids, they may be more or less useful as characters for these groups based on this frequency.

This is especially relevant when considering the growing number of fossil diapsid taxa with more complex crown morphologies (Clark et al. 1989; Wu and Sues 1996; Larsson and Sidor 1999; Buckley et al. 2000; Nydam et al. 2000; Pol 2003; O" si et al. 2007). The generic view of diapsid dentitions is one of a series of nonoccluding identical conical teeth. But cusp morphology in diapsids is much more diverse that that, including the formation of carinae that in some taxa are serrated and even the teeth of non-mammalian amniotes can be different enough from each other to be classified as heterodont (Hungerbu" hler 2000; Smith 2005). The succession of teeth from juvenile to adult teeth of some modern diapsids, including teiids, can change size and morphology dramatically with age (Estes and Williams 1984; Dessem 1985; Berkovitz 2000). Also, many modern and fossil taxa are know to have multiple cusps that superficially resemble mammalian teeth and may have served in insectivory or even herbivory (Clark et al. 1989; Wu and Sues 1996; Larsson and Sidor 1999; Buckley et al. 2000; Nydam et al. 2000; Pol 2003; Osi et al. 2007). This diversity of cusp morphologies clearly shows some selective pressure for enhancing the use of teeth on food processing, as many modern taxa with more complex crown morphologies (such as Dracaena and Tupinambis) teeth have been observed using these teeth for molar-like purposes (Dalrymple 1979).

Despite these more extreme and obvious adaptations, it is unclear how more subtle changes in simpler teeth occur. At first glance it appears that most of these complex crowns are elaborations of the carinae and their serrations, as many of these teeth appear to have these cusps aligned along a mesiodistal axis like the carinae of normal conical archosauriform teeth. 
We still do not know if these unusual dentitions are all the result of changes in dentine like carinae or if this crown morphology forms from changes in enamel thickness and/or structure. Even more difficult to identify are cases in which observed morphology is potentially simply polymorphic or ontogenetic variants (Estes and Williams 1984) and not related to such functional needs. Simple conical teeth can be used for such purposes as well, and some modern caimans have been observed possibly engaged in fruit eating (Brito et al. 2002). The potential for multifunctional purposes of the ziphodont teeth of archosaurs is perhaps why their use in determining diets, and even their utility in diagnosing taxa, can be difficult (Irmis et al. 2007b).

So, could it be that, like mammals, archosaurs and other diapsids experience some selective pressure for more complex tooth shapes? If so, could developmental plasticity, perhaps in something simple such as the carina, allow for such opportunities within the Archosauria? These few incidences of a developmental anomaly are not enough to begin answering this, but perhaps suggest that complex crown morphology in diapsids are developmentally plastic throughout large clades, and that this plasticity may have allowed for the multiple incidences in the fossil record in which we see diapsids take advantage of the use of more complex teeth. If archosaurs and other diapsids are limited to changes in crown morphology by changes in the dentine and not enamel, could this explain why mammalian dentitions are so much more dramatically diverse in morphology?

\section{ACKNOWLEDGEMENTS}

Reviews by Stephen Brusatte and one anonymous reviewer significantly improved the manuscript. For assistance with specimens studied we would like to thank S. Lucas (NMMNH). D.C. Heckert found the tooth while assisting A.B. Heckert with field work for his M.S. Thesis. The tooth was collected under a permit issued to the NMMNH for vertebrate fossil collection by the Cibola National Forest. D. Ulibarri (NMMNH) expertly moulded and cast the specimen for our analyses. 


\section{REFERENCES}

Abler WL. 1992. The serrated teeth of tyrannosaurid dinosaurs, and biting structures in other animals. Paleobiology. 18(2):161-183.

Abler WL. 1997. Tooth serrations in carnivorous dinosaurs. In: Currie PJ, Padian K, editors. Encyclopedia of dinosaurs. New York (NY): Academic Press. p. 740-743.

Alcober O. 2000. Redescription of the skull of Saurosuchus galilei (Archosauria: Rauisuchidae). J Vertebr Paleontol. 20(2):302-316.

Barrett PM. 2000. Prosauropod dinosaurs and iguanas: speculations on the diets of extinct reptiles. In: H-D Sues, editor. Evolution of herbivory in terrestrial vertebrates: perspectives from the fossil record. Cambridge (UK): Cambridge University Press. p. 42-78.

Becker MA, Chamberlain JA, Stoffer PW. 2000. Pathologic tooth deformities in modern and fossil chondrichthians: a consequence of feeding-related injury. Lethaia. 33(2):103-118.

Berkovitz BK. 2000. Tooth replacement patterns in non-mammalian vertebrates. In: Teaford MF, Smith MM, Ferguson MWJ, editors.

Development, function and evolution of teeth. Cambridge (UK): Cambridge University Press. p. 186-200.

Bohlin B. 1953. Fossil reptiles from Mongolia and Kansu. In: Reports from the scientific expedition to the north-western provinces of

China, Sino-Swedish expedition, Publication 37: VI. Vertebrate palaeontology 6. Stockholm (Sweden): Statens Etnografiska Museum. p. 1-113.

Brito S, Andrade DV, Abe AS. 2002. Do caimans eat fruit? Herpetol Nat Hist. 9(1):95-96.

Brusatte SL, Benton MJ, Ruta M, Lloyd GT. 2008. Superiority, competition, and opportunism in the evolutionary radiation of dinosaurs. Science. 321:1485-1488.

Buchtova' M, Handrigan GR, Tucker AS, Lozanoff S, Town L, Fu K, Diewert VM, Wicking C, Richman JM. 2008. Initiation and patterning of the snake dentition are dependent on sonic hedgehog signaling. Dev Biol. 319(1):132-145.

Buckley GA, Brochu CA, Krause DW, Pol D. 2000. A pug-nosed crocodyliform from the Late Cretaceous of Madagascar. Nature. 405(6789):941-944.

Candeiro CRA, Tanke DH. 2008. A pathological Late Cretaceous carcharodontosaurid tooth from Minas Gerais, Brazil. Bull Geosci. 83(3):351-354.

Carpenter K. 1997. A giant coelophysoid (Ceratosauria) theropod from the Upper Triassic of New Mexico, USA. Neues Jahrb Geol Pal., Abh. 205:189-206. 
Chatterjee S. 1985. Postosuchus, a new thecodontian reptile from the Triassic of Texas and the origin of tyrannosaurs. Phil Trans R Soc Lond (B). 309:395-460.

Clark JM, Jacobs LL, Downs WR. 1989. Mammal-like dentition in a Mesozoic crocodylian. Science. 244:1064-1066.

Currie PJ. 1987. Bird-like characteristics of the jaws and teeth of troodontid theropods (Dinosauria, Saurischia). J Vertebr Paleontol. 7(1):72-81.

Dalrymple GH. 1979. On the jaw mechanism of the snail-crushing lizards, Dracaena Daudin 1802 (Reptilia, Lacertilia, Teiidae). J Herpetol. 13(3):303-311.

Davis JI, Nixon KC. 1992. Populations, genetic variation, and the delimitation of phylogenetic species. Syst Biol. 41(4):421-435.

Delgado S, Davit-Be'al T, Allizard F, Sire J-Y. 2005. Tooth development in a scincid lizard, Chalcides viridanus (Squamata), with particular attention to enamel formation. Cell Tissue Res. 319(1):71-89.

Desojo JB, Ba'ez AM. 2007. Cranial morphology of the Late Triassic South American archosaur Neoaetosauroides engaeus: evidence for aetosaurian diversity. Palaeontology. 50(1):267-276.

Dessem D. 1985. Ontogenetic changes in the dentition and diet of Tupinambis (Lacertilia:

Teiidae). Copeia. 1985(1):245-247.

Dubrovo IA, Sanders AE. 2000. A new species of Patriocetus (Mammalia, Cetacea) from the Late Oligocene of Kazakhstan. J Vertebr Paleontol. 20(3):577-590.

Duellman WE, Trueb L. 1986. The biology of amphibians. New York: McGraw Hill.

Edmund AG. 1960. Tooth replacement phenomena in the lower vertebrates. Life Sci Contrib, Royal Ontario Museum. 52:1-190.

Edmund AG. 1962. Sequence and rate of tooth replacement in the Crocodilia. Life Sci Contrib, Royal Ontario Museum. 56:1-42.

Erickson GM. 1995. Split carinae on tyrannosaurid teeth and implications of their development. J Vertebr Paleontol. 15(2):268-274.

Erickson GM. 1996. Incremental lines of von Ebner in dinosaurs and the assessment of tooth replacement rates using growth line counts. Proc Natl Acad Sci USA. 93(25):14623-14627.

Estes R, Williams EE. 1984. Ontogenetic variation in the molariform teeth of lizards. J Vertebr Paleontol. 4(1):96-107.

Farlow JO, Brinkman DL, Abler WL, Currie PJ. 1991. Size, shape and serration density of theropod dinosaur lateral teeth. Mod Geol. 16: 161-198. 
Fiorillo AR, Gangloff RA. 2000. Theropod teeth from the Prince Creek Formation (Cretaceous) of northern Alaska, with speculations on arctic dinosaur paleoecology. J Vertebr Paleontol. 20(4):675-682.

Frazzetta TH. 1988. The mechanics of cutting and the form of shark teeth (Chondrichthyes, Elasmobranchii). Zoomorphology. 108(2): 93-107.

Furin S, Preto N, Rigo M, Roghi G, Gianolla P, Crowley JL, Bowring SA. 2006. High-precision $\mathrm{U}-\mathrm{Pb}$ zircon age from the Triassic of Italy: in reply to implications for the Triassic time scale and the Carnian origin of calcareous nannoplankton and dinosaurs. Geology. 34(12):1009-1012.

Galton PM. 1986. Herbivorous adaptations of Late Triassic and Early Jurassic dinosaurs. In: K Padian, editor. The beginning of the age of dinosaurs - faunal change across the TriassicJurassic boundary. Cambridge (UK): Cambridge University Press. p. 203-221.

Gauthier J. 1994. The diversification of the amniotes. In: Spencer RS, editor. Major features of vertebrate evolution. Knoxville (TN): The Paleontological Society. p. 129-159.

Godefroit P, Cuny G. 1997. Archosauriform teeth from the Upper Triassic of Saint-Nicolas-dePort. Palaeovertebrata. 26:1-34.

Gower DJ. 2000. Rauisuchian archosaurs (Reptilia, Diapsida): an overview. Neues Jahrb Geol Pal., Abh. 218:447-488.

Gower DJ. 2003. Osteology of the early archosaurian reptile Erythrosuchus africanus broom. Ann S Afr Museum. 110:1-88.

Hall PM. 1985. Brachycephalic growth and dental anomalies in the New Guinea crocodile (Crocodylus novaeguineae). J Herpetol. 19(2):300-303.

Harris MP, Hasso SM, Ferguson MWJ, Fallon JF. 2006. The development of archosaurian firstgeneration teeth in a chicken mutant. Curr Biol. 16(4):371-377.

Heckert AB. 1997. The tetrapod fauna of the Upper Triassic lower Chinle Group (Adamanian: latest Carnian), of the Zuni Mountains, westcentral New Mexico. New Mex Mus Nat Hist Sci Bull. 11:29-39.

Heckert AB. 2004. Late Triassic microvertebrates from the lower Chinle Group (OtischalkianAdamanian: Carnian), southwestern USA. New Mex Mus Nat Hist Sci Bull. 27:1-170.

Heckert AB, Lucas SG. 2000a. Taxonomy, phylogeny, biostratigraphy, biochronology, paleobiogeography, and evolution of the Late Triassic Aetosauria (Archosauria: Crurotarsi). Zbl Geo Pal. Heft 11-12:1539-1587.

Heckert AB, Lucas SG. 2000b. Global correlation of the Triassic theropod record. Gaia. 15:6374.

Heckert AB, Lucas SG. 2003. Triassic stratigraphy in the Zuni Mountains, west-central New Mexico. New Mex Geol Soc Guidebook. 54:245-262. 
Hungerbu" hler A. 2000. Heterodonty in the European phytosaur Nicrosaurus kapffi and its implications for the taxonomic utility and functional morphology of phytoaur dentitions. J Vertebr Paleontol. 20(1):31-48.

Heckert AB, Lucas SG, Hunt AP. 2005. Triassic vertebrate fossils in Arizona. New Mex Mus Nat Hist Sci Bull. 29:16-44.

Heckert AB, Lucas SG, Spielmann JA, Hunt AP. 2007. Biostratigraphic utility of the Upper Triassic aetosaur Tecovasuchus (Archosauria: Stagonolepididae), an index taxon of St. Johnsian (Adamanian: Late Carnian) time. New Mex Mus Nat Hist Sci Bull. 41:51-57.

Hunt AP. 1989. Cranial morphology and ecology among phytosaurs. In: Lucas SG, Hunt AP, editors. Dawn of the age of dinosaurs in the American southwest. Albuquerque (NM): New Mexico Museum of Natural History. p. 349-354.

Irmis RB, Nesbitt SJ, Padian K, Smith ND, Turner AH, Woody D, Downs A. 2007a. A Late Triassic dinosauromorph assemblage from New Mexico and the rise of dinosaurs. Science. 317:358-361.

Irmis RB, Parker WG, Nesbitt SJ, Liu J. 2007b. Early ornithischian dinosaurs: the Triassic record. Hist Biol. 19(1):3-22.

Jalil N, Peyer K. 2007. A new rauisuchian (Archiosauria Suchia) from the Upper Triassic of the Argana Basin, Morocco. Palaeontol. 50: 417-430.

Kassai Y, Munne P, Hotta Y, Penttila E, Kavanaugh K, Ohbayashi N, Takada S, Thesleff I, Jernvall J, Itoh N. 2005. Regulation of mammalian tooth cusp patterning by ectodin. Science. 309: 2067-2070.

Langer MC, Benton MJ. 2006. Early dinosaurs: a phylogenetic study. J Syst Palaeontol. 4:309_ 358.

Langston W. 1956. The Sebecosuchia: cosmopolitan crocodilians? Am J Sci. 254:605-614.

Larsson HCE, Sidor CA. 1999. Unusual crocodyliform teeth from the Late Cretaceous (Cenomanian) of Southeastern Morocco. J Vertebr Paleontol. 19(2):398-401.

Long RA, Murry PA. 1995. Late Triassic (Carnian and Norian) tetrapods from the southwestern United States. New Mex Mus Nat Hist Sci Bull. 4:254.

Lucas SG, Heckert AB, Hunt AP. 1997. Lithostratigraphy and biostratigraphic significance of the Placerias quarry, east-central Arizona. Neues Jahrb Geol Pal., Abh. 203:23-46.

Lucas SG, Hunt AP, Heckert AB, Spielmann JA. 2007. Global Triassic tetrapod biostratigraphy and biochronology: 2007 status. New Mex Mus Nat Hist Sci Bull. 41:229-240.

Martin LD. 1980. Functional morphology and the evolution of cats. Trans Nebraska Acad Sci. 7:141-154. 
Nesbitt SJ. 2005a. A new archosaur from the upper Moenkopi Formation (Middle Triassic) of Arizona and its implications for rauisuchian phylogeny and diversification. Neues Jahrb Geol Pal., Abh. 2005(6): 332-346.

Nesbitt SJ. 2005b. Osteology of the Middle Triassic pseudosuchian archosaur Arizonasaurus babbitti. Hist Biol. 17:19-47.

Nesbitt SJ, Irmis RB, Lucas SG, Hunt AP. 2005. A giant crocodylomorph from the Upper Triassic of New Mexico. Pala"ontologische Zeitschrift. 79:471-478.

Nydam RL, Gauthier JA, Chiment JJ. 2000. The mammal-like teeth of the late Cretaceous lizard Peneteius aquilonius Estes 1969 (Squamata, Teiidae). J Vertebr Paleontol. 20(3):628-631.

Osi A, Clark JM, Weishampel DB. 2007. First report on a new basal eusuchian crocodyliform with multicusuped teeth from the Upper Cretaceous (Santonian) of Hungary. Neues Jahrb Geol Pal., Abh. 304:169-177.

Peyer B. 1968. Comparative odontology. Chicago (IL): The University of Chicago Press. 347 p.

Pol D. 2003. New remains of Sphagesaurus huenei (Crocodylomorpha: Mesoeucrocodylia) from the late Cretaceous of Brazil. J Vertebr Paleontol. 23(4):817-831.

Purslow PP. 1991. Measuring meat texture and understanding its structural basis. In: Vincent JFV, Lillford PJ, editors. Feeding and the texture of food. Cambridge (UK): Cambridge University Press. p. 35-56.

Romer AS. 1971. The Chañares (Argentina) Triassic reptile fauna. XI. Two new long-snouted thecodonts, Chanaresuchus and Gualosuchus. Breviora. 379:1-22.

Sander PM. 1999. The microstructure of reptilian tooth enamel: terminology, function, and phylogeny. Munchner Geowissenschaftliche Abhandlungen. 38:1-102.

Sereno PC. 1991. Basal archosaurs: phylogenetic relationships and functional implications. Soc Vertebr Paleontol Mem. 2:1-53.

Sereno PC, Brusatte SL. 2008. Basal abelisaurid and carcharodontosaurid theropods from the Lower Cretaceous Elrhaz Formation of Niger. Acta Palaeontol Pol. 53(1):15-46.

Shintani S, Kobata M, Toyosawa S, Fujiwara T, Sato A, Ooshima T. 2002. Identification and characterization of ameloblastin gene in a reptile. Gene. 283(1-2):245-254.

Shintani S, Kobata M, Toyosawa S, Ooshima T. 2006. Expression of ameloblastin during enamel formation in a crocodile. J Experiment Zool B: Molec Develop Evol. 306B(2):126-133.

Sill WD. 1974. The anatomy of Saurosuchus galilei and the relationships of the rauisuchid thecodonts. Bull Mus Comparative Zool. 146: 317-362.

Sire J-Y, Davit-Be'al T, Delgado S, Gu X. 2007. The origin and evolution of enamel mineralization genes. Cells Tissues Organs. 186(1): 25-48. 
Smith JB. 2005. Heterodonty in Tyrannosaurus rex: implications for the taxonomic and systematic utility of theropod dentitions. J Vertebr Paleontol. 25(4):865-887.

Smith JB, Vann DR, Dodson P. 2005. Dental morphology and variation in

theropod dinosaurs: implications for the taxonomic identification of isolated teeth. Anat Rec A: Discov Molec Cell Evol Biol. 285A(2): 699-736.

Thesleff I. 2003. Epithelial-mesenchymal signalling regulating tooth morphogenesis. J Cell Sci. 116(9):1647-1648.

Throckmorton GS. 1976. Oral food processing in two herbivorous lizards, Iguana iguana (Iguanidae) and Uromastix aegyptius (Agamidae). J Morphol. 148(3):363-390.

Toyosawa S, O'hUigin C, Tichy H, Klein J. 1999. Characterization of dentin matrix protein 1 gene in crocodilia. Gene. 234(2):307-314.

Toyosawa S, O'hUigin C, Figueroa F, Tichy H, Klein J. 1998. Identification and characterization of amelogenin genes in monotremes, reptiles, and amphibians. Proc Natl Acad Sci USA. 95(22): 13056-13061.

Uhen MD. 2008. Dental morphology, Evolution of. In: Perrin WF, Wursig B, Thewissen JGM, editors. Encyclopedia of marine mammals. 2nd ed. New York (NY): Academic Press. p. 302307.

von Meyer H. 1861. Reptilien aus dem Stubensandstein des oberen Keupers. Palaeontographica. 7:253-300.

Walker AD. 1964. Triassic reptiles from the Elgin area: Ornithosuchus and the origin of carnosaurs. Phil Trans R Soc B. 248:53-134.

Westergaard B, Ferguson MWJ. 1986. Development of the dentition in Alligator mississippiensis. Early embryonic development in the lower jaw. J Zool London. 210:575-597.

Westergaard B, Ferguson MWJ. 1990. Development of the dentition in Alligator mississippiensis: upper jaw dental and craniofacial development in embryos, hatchlings, and young juveniles, with a comparison to lower jaw development. Am J Anat. 187(4):393-421.

Wu X-C, Sues H-D. 1996. Anatomy and phylogenetic relationships of Chimaerasuchus paradoxus, an unusual crocodyliform reptile from the Lower Cretaceous of Hubei, China. J Vertebr Paleontol. 16(4): 688-702. 